\title{
Magnetic inversion in the East China Sea and Okinawa Trough: tectonic implications
}

\author{
Shu-Kun Hsu ${ }^{\mathrm{a}, *}$, J.-C. Sibuet ${ }^{\mathrm{b}}$, Chuen-Tien Shyu ${ }^{\mathrm{c}}$ \\ anstitute of Geophysics, National Central University, Chung-Li, Taiwan, ROC \\ bIfremer, Centre de Brest, Plouzané 29280, France \\ ${ }^{\mathrm{c}}$ Institute of Oceanography, National Taiwan University, Taipei, Taiwan, ROC
}

Received 22 June 1999

\begin{abstract}
In order to better understand continental rifting along the eastern margin of the Eurasian plate, we have performed a magnetic inversion to reveal the distribution and characteristics of the belts and basins in the East China Sea and Okinawa Trough. Equivalent magnetizations are obtained by assuming a constant thickness of $5 \mathrm{~km}$ of the magnetized layer whose top surface is assigned to the sea floor and taking into account the present-day geomagnetic field. Because of absence of magnetic reversals in the study area, a high-magnetization zone can reflect a shallow and/or highly magnetized basement. In contrast, a lowmagnetization zone generally corresponds to a rifted basin with thick sediments.

The belts in the East China Sea shelf basin are in general below sea level and correspond to shallow basement with thin sediments. The inversion results show that the belts are parallel and trending about $\mathrm{N} 075^{\circ}$. This regular trend suggests a simple, southeastward rifting pattern of the East China Sea shelf basin. The belt trend changes from $\mathrm{N} 075^{\circ}$ to $\mathrm{N} 095^{\circ}$ at the eastern side of the Taiwan-Sinzi belt. Southwest of the Taiwan-Sinzi belt, the belts in the Ryukyu subduction system are parallel to the Ryukyu trench. It implies that rifting of the middle and northern Okinawa Trough was initiated along the eastern side of the Taiwan-Sinzi belt; then the rifting has been mainly controlled by the oblique subduction of the Philippine Sea plate beneath the Ryukyu arc.

The southern end of the Taiwan-Sinzi belt terminates at the NW-SE-trending Miyako-Yandang high-magnetization zone. The southern Okinawa Trough, rifted since early Pleistocene, is distinct from the middle and northern Okinawa Trough by the Miyako-Yandang high-magnetization zone. The southern Okinawa Trough consists of two rifting patterns: east of $123.5^{\circ} \mathrm{E}$, the backarc rifting is quasi-symmetric as evidenced by symmetrically high magnetization zones on both sides of the Yaeyama Depression. In contrast, west of $123.5^{\circ} \mathrm{E}$, the volcanism or high magnetization zones, developed along existing NW-SE-trending strike-slip faults, have generally occurred at the northern margin of the southern Okinawa Trough. The Ryukyu arc, west of $123.5^{\circ} \mathrm{E}$, exhibits low magnetization reflecting its non-volcanic nature of the upper crust. East of $123.5^{\circ} \mathrm{E}$, the present-day Ryukyu arc volcanism is expressed by relatively high magnetization. (ㅇ) 2001 Elsevier Science B.V. All rights reserved.
\end{abstract}

Keywords: magnetic inversion; Okinawa Trough; tectonic implications

* Corresponding author. Fax: +886-2-4222044.

E-mail address: hsu@oc.gep.ncu.edu.tw (S.-K. Hsu).

\section{Introduction}

The eastern margin of the Eurasian plate consists of two main basins, the East China Sea shelf and the Okinawa Trough basin (Fig. 1), bounded by three 


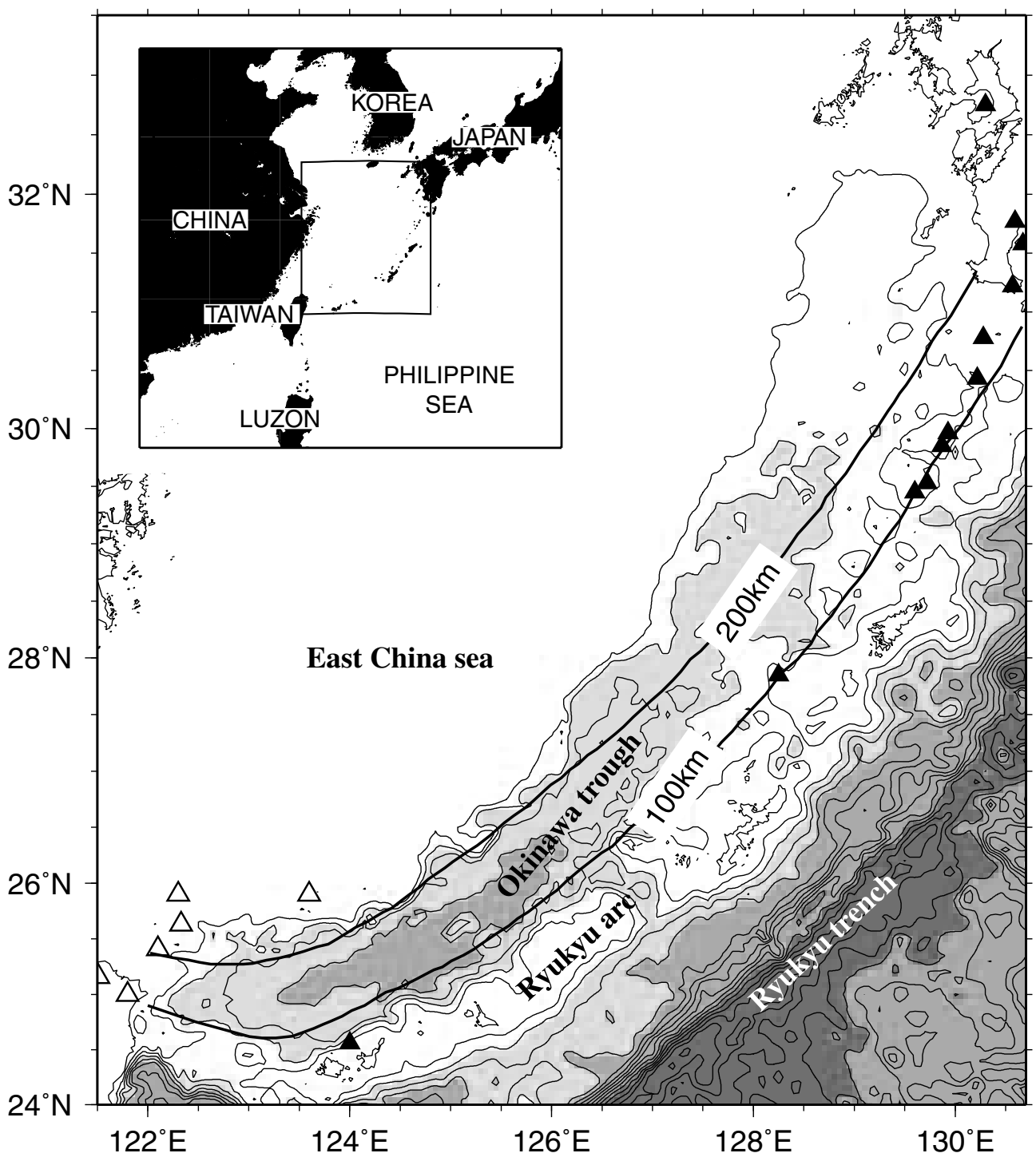

$1-2 \mathrm{~km}$ deep
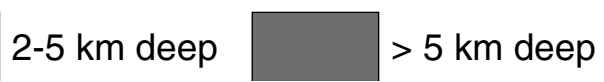

Fig. 1. Location of the study area. Bathymetry greater than $1000 \mathrm{~m}$ is shaded. Contour interval is $500 \mathrm{~m}$. Heavy lines with 100 or $200 \mathrm{~km}$ represent the distribution of the 100 and $200 \mathrm{~km}$ isocontours of the Wadati-Benioff zone, which are outlined on the basis of the ISC earthquake catalog. Open triangles indicate the Quaternary and late Pliocene volcanoes of the Northern Taiwan Volcanic Zone. Solid triangles indicate location of the present-day Ryukyu arc volcanism.

main, high-topography belts. From the Chinese mainland to the Ryukyu trench, they are the Zhemin belt, the Taiwan-Sinzi belt and the Ryukyu arc (Fig. 2). The shelf basin is divided into a series of sub-basins trending more or less parallel to the coastline of the Chinese mainland (Fig. 2). Faults in this area follow two principal trends, a NE direction, which corresponds to normal faults bounding rifted basins and a 
NW direction, which generally corresponds to strikeslip faults (Liu, 1992). According to the interpretation of geophysical and drilling data, extensive magmatic activities existed from Mesozoic to Quaternary (Sun, 1981; Liu, 1992). Continental rifting appears to be younger toward southeast (Sun, 1981; Liu, 1992; Huang et al., 1992; Sibuet and Hsu, 1997).

Among the rifted basins, the initial opening of the southeastern most basin, the Okinawa Trough, was considered to be of Late Miocene age (Lee et al., 1980; Letouzey and Kimura, 1986; Sibuet et al., 1987). The Miocene extension for the middle and northern Okinawa Trough may be related to the opening of the Japan Sea and associated with a major dextral strike-slip fault along the east side of the Taiwan-Sinzi belt (Le Pichon and Mazzotti, 1997). However, the paleomagnetic and marine geophysical data suggest that the formation of the southern Okinawa Trough is different from the middle and northern Okinawa Trough (Miki, 1995; Hsu et al., 1996). This difference is also revealed by the gravity anomaly features: the Taiwan-Sinzi belt and the Ryukyu arc are marked by high-gravity anomalies, which bend from NE-SW trending to E-W or WNW-ESE trending between $124^{\circ} \mathrm{E}$ and $125^{\circ} \mathrm{E}$ (Fig. 3). Furthermore, the seismic stratigraphy suggests that rifting of the southern Okinawa Trough is early Pleistocene (Park et al., 1998). The formation of the Okinawa Trough is thus complex, involving a multiphase opening.

To date, a complete visualization and relationship of the basins and ridges in the East China Sea and Okinawa Trough is absent. Because sediments generally reflect very low magnetic susceptibilities, and thus low magnetization, with respect to the underlying basement volcanic rocks, magnetic inversion can be used to understand the distribution of the rifted basin and associated ridges. We address in this paper the tectonic implications of a 3D magnetic inversion performed over the East China Sea and Okinawa Trough basins.

\section{Data processing}

Two data sets of total-field magnetic anomalies are used in this study. The first comes from the magnetic anomalies compiled by the CCOP (Magnetic Anomaly
Map of East Asia, 1994) (Fig. 4a). This data set is adequate for giving a general overview of the equivalent magnetization distribution. A grid spacing of $10 \mathrm{~km} \times 10 \mathrm{~km}$ is adopted for the magnetic data. The equivalent magnetization of each block is obtained by inverting the magnetic data in the sense of least-square error (Menke, 1984). To reduce the topographic effect, the bathymetric data from Global Sea Floor Topography of Smith and Sandwell (1997) are used. The bathymetry is gridded at the same spacing as the magnetic data. The top of each block is assigned to be at the sea floor and the thickness of each block is set to $5 \mathrm{~km}$. The inversion calculation is accomplished by using the LSQR algorithm (Paige and Saunders, 1982). For convenience, we have assumed that the magnetization inclination of each block is $35^{\circ}$ and the declination $\mathrm{N} 3.5^{\circ} \mathrm{E}$, which are the present-day parameters in this area. This assumption is reasonable because of the following two reasons. First, from our experience, an error of several degrees of the magnetization inclination or declination estimation would not cause significant changes in the inversion result. Secondly, this area is floored with thinned continental crust and no magnetic reversals or oceanic sea floor spreading are identified (e.g. Sibuet et al., 1987; Oshida et al., 1992; Liu, 1992; Sibuet et al., 1995). The resulting magnetization distribution is shown in Fig. 4b. We interpret the positive magnetization as the location of belts and the relatively low magnetization as basins (Fig. 5). It is noted that the distribution of the basins and belts in Fig. 2 are obtained by taking into account available seismic reflection profiles and drilling data (Liu, 1992). Compared to Fig. 2, Fig. 5 displays similar major structural features such as the location of the Zhemin belt, the Taiwan-Sinzi belt and the Ryukyu belt.

The second database used for this study is a compilation of newly released magnetic data in Hsu et al. (1998) and Sibuet et al. (1995). The data have better resolution than the previous ones, but are limited to the southern Okinawa Trough (Fig. 6a). Bathymetric data of higher resolution are also available in this region (Sibuet et al., 1998; Liu et al., 1998; Hsu et al., 1996). Thus, we gridded the magnetic and bathymetric data into $4 \mathrm{~km} \times 4 \mathrm{~km}$ grid spacing. The thickness of each block was also set at $5 \mathrm{~km}$. The same inversion algorithm was applied. Compared to 


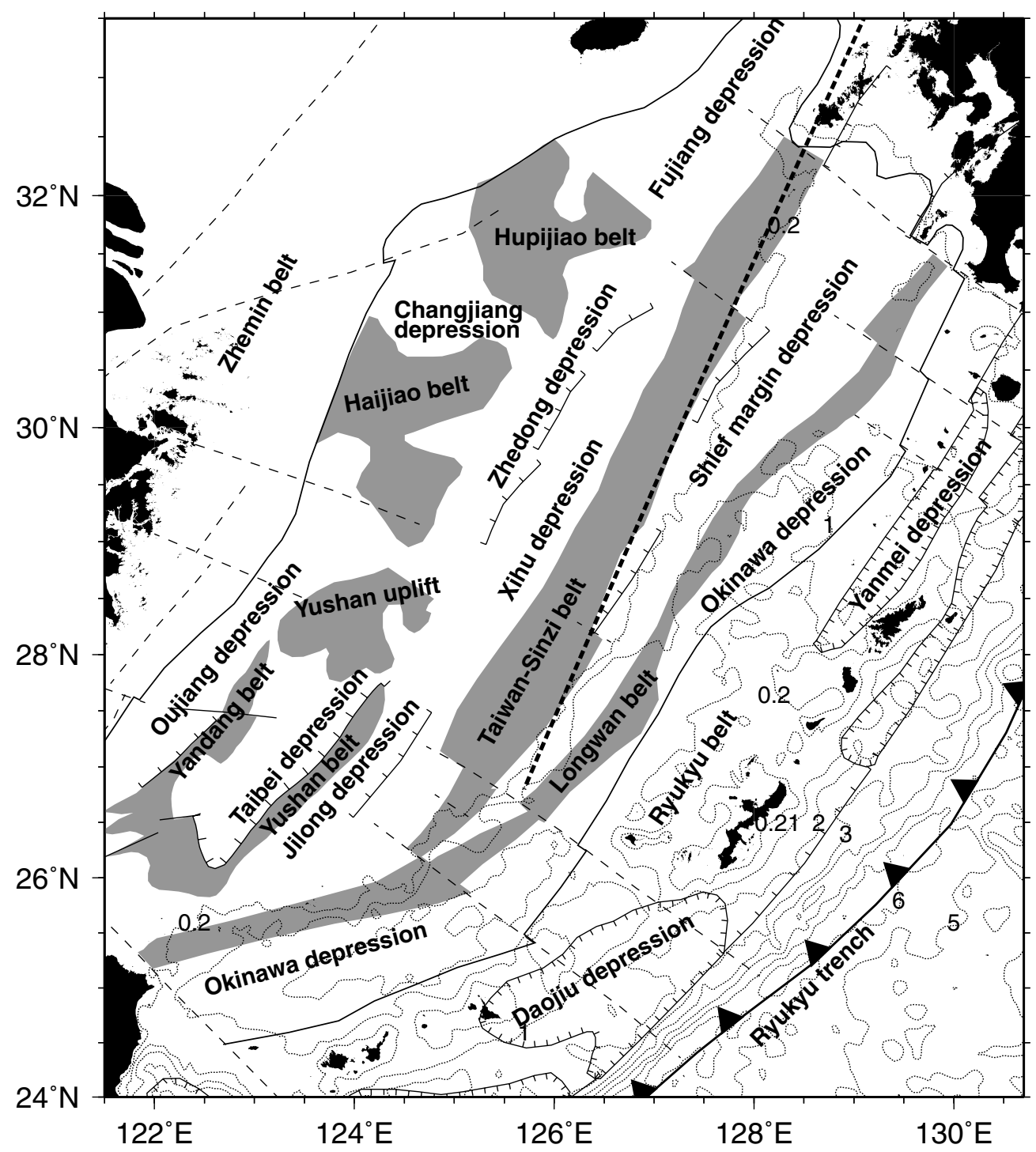

Fig. 2. Tectonic framework of the study area (modified mainly from Sun (1981) and Liu (1992)). Dotted lines, respectively, represent bathymetric contours of $0.2,1,2,3,4,5,6 \mathrm{~km}$. Dashed lines indicate possible strike-slip faults. Heavy dashed line indicates the possible dextral fault proposed by Le Pichon and Mazzotti (1997).

Fig. $4 \mathrm{~b}$, the obtained equivalent magnetizations (Fig. 6b) present better resolution. The ridges and basins inferred from the magnetization distribution are shown in Fig. 7.

Do the high magnetization areas reflect the existence of the belts and low magnetization areas correspond to the rifted basins? Because the southern Okinawa Trough contains volcanic intrusions or extrusive seamounts (Sibuet et al., 1987, 1998), the question can be answered by comparing some highmagnetization areas in Fig. 7 with available seismic reflection profiles (e.g. Furukawa et al., 1991) or highresolution bathymetric data (e.g. Sibuet et al., 1998). As indicated by numbers 1-9 (Fig. 7), the volcanic intrusions or sea knolls are revealed by the relatively high magnetizations (Figs. $6 \mathrm{~b}$ and 7). 


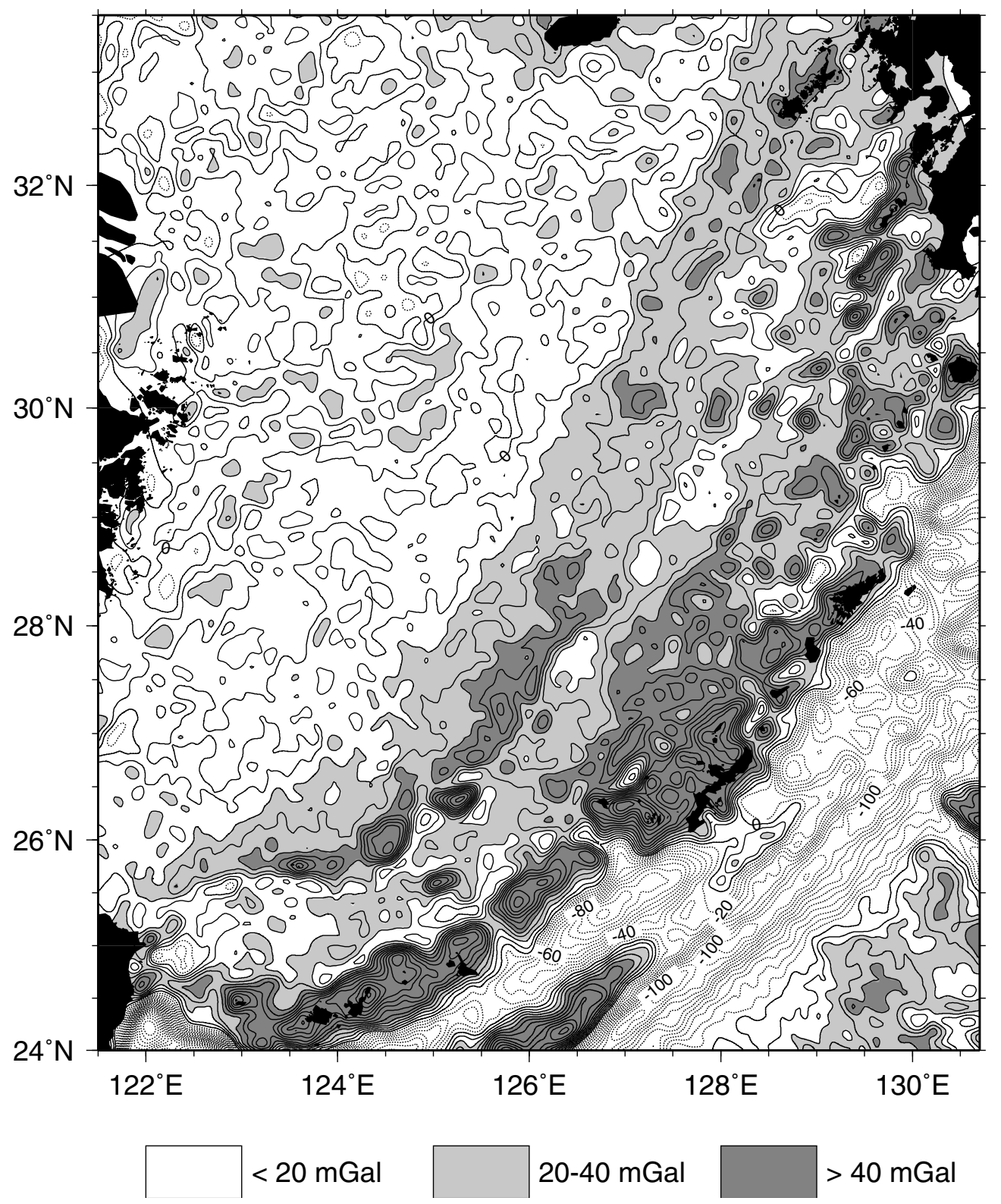

Fig. 3. Free-air gravity anomalies of the study area (from Smith and Sandwell, 1997). Gravity anomalies greater than $20 \mathrm{mGal}$ are shaded. Gravity anomalies less than zero are plotted by dashed lines. Contour interval is $10 \mathrm{mGal}$. Note that the Taiwan-Sinzi belt and the Ryukyu arc are revealed by high-gravity anomalies.

\section{Magnetic features and new tectonic insights}

\subsection{Trends and amplitudes of the volcanic belts}

As shown in Figs. 4b and 5, the belts in the East
China Sea shelf basin (i.e. from the Zhemin belt to the Taiwan-Sinzi belt) are highly parallel and generally trending NEN-SWS $\left(\sim \mathrm{N} 075^{\circ}\right)$. This regular orientation of the belts in the East China Sea continental shelf seems to imply that the eastern Eurasian margin has 

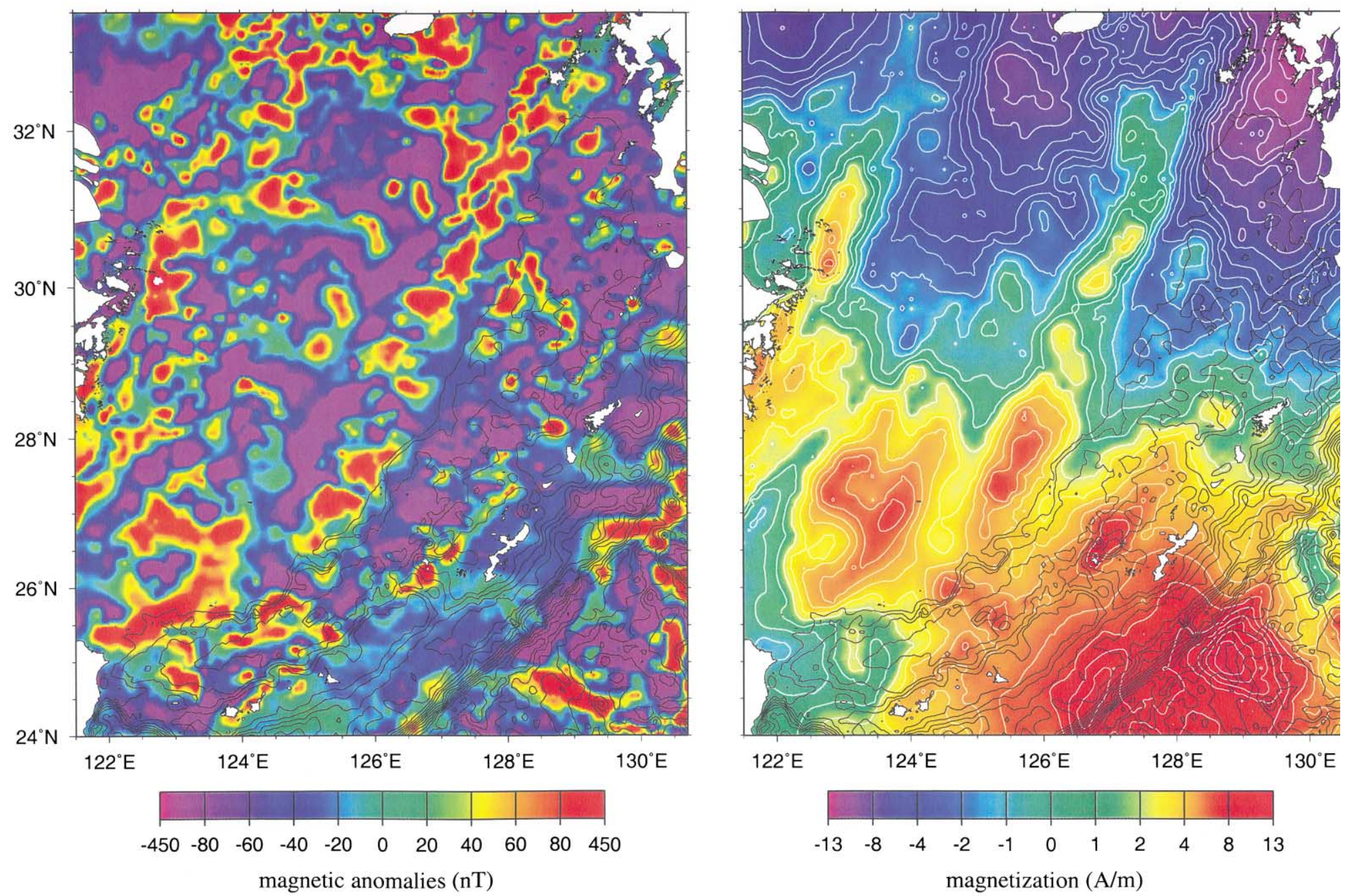

政

Fig. 4. (a) (Left) Magnetic anomalies of the study area (Magnetic Anomaly Map of East Asia, 1994). Bathymetric data of $500 \mathrm{~m}$ contour interval is superposed. (b) (Right) The equivalent magnetization of the same area as Fig. 4 a. See the inversion algorithm and explanation in the text. 


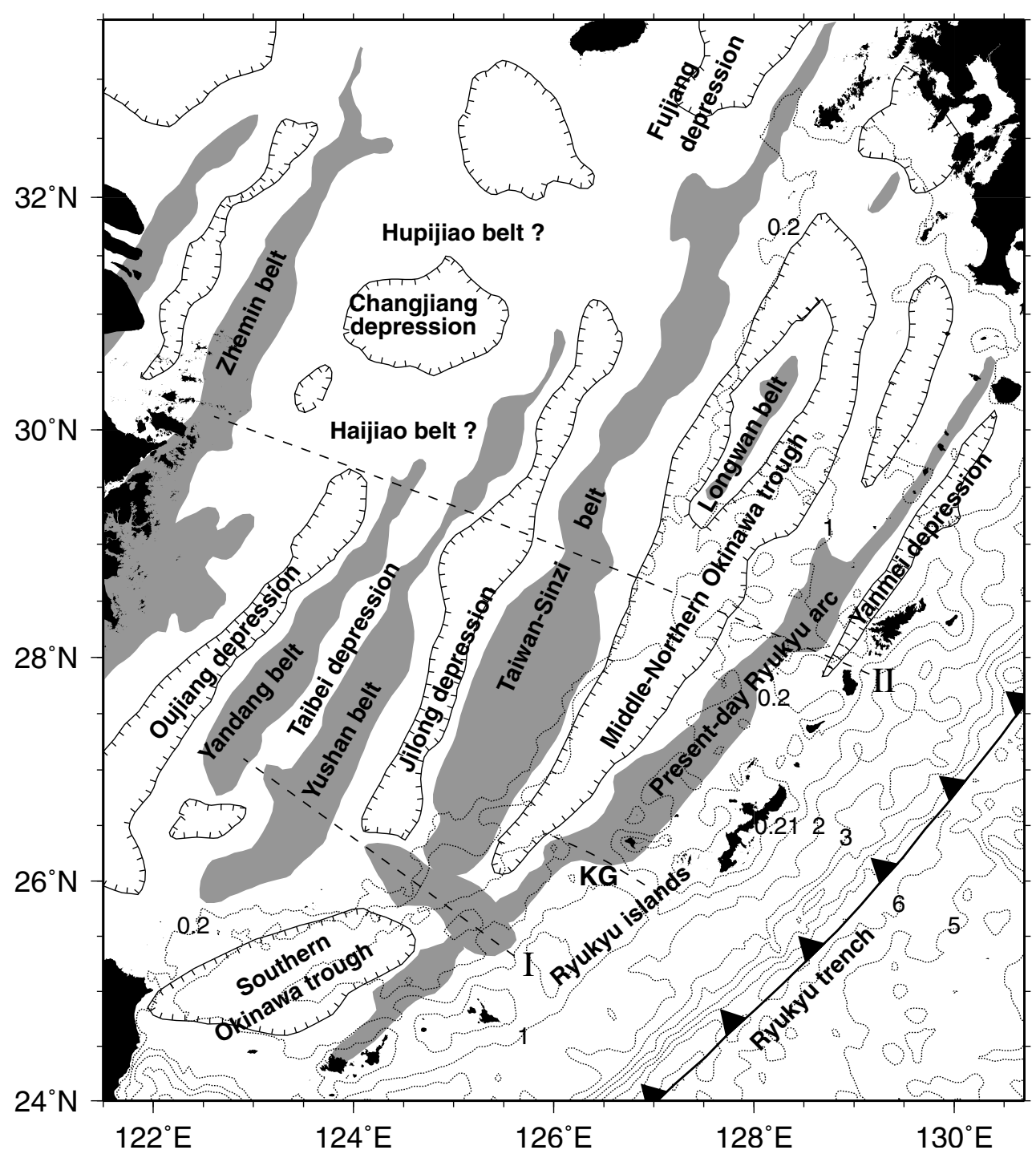

Fig. 5. Interpreted tectonic framework of the study area on the basis of the distribution of the magnetization in Fig. 4b. KG: Kerama Gap. Dashed lines indicated by I and II, respectively, generally separate the distribution of the inverted magnetization into three domains. Highmagnetization zone along structure I is named the "Miyako-Yandang high magnetization zone".

been under a simple, southeastward rifting regime. However, the trend changes drastically beyond the Taiwan-Sinzi belt. Southeast of the Taiwan-Sinzi belt, the Longwan belt, the present-day Ryukyu arc and the Ryukyu island arc are parallel to the Ryukyu trench (Fig. 5). The change in trend between the present-day Ryukyu arc and the Taiwan-Sinzi belt suggests a clockwise rotation of $\sim 20^{\circ}$ about an Euler pole near $123.4^{\circ} \mathrm{E}$ and $24^{\circ} \mathrm{N}$. The pole is located at the place where the Ryukyu arc bends from NE trending to NWW trending (Fig. 4b). In contradiction to Liu (1992), the Longwan belt is only present in the northern portion of the northern Okinawa Trough (cf. Figs. 2 and 5). In summary, the resulting magnetizations indicate two main trends of the volcanic belts in the study area: the belts in the East China Sea shelf basin are generally NEN-SWS trending, whereas the belts 

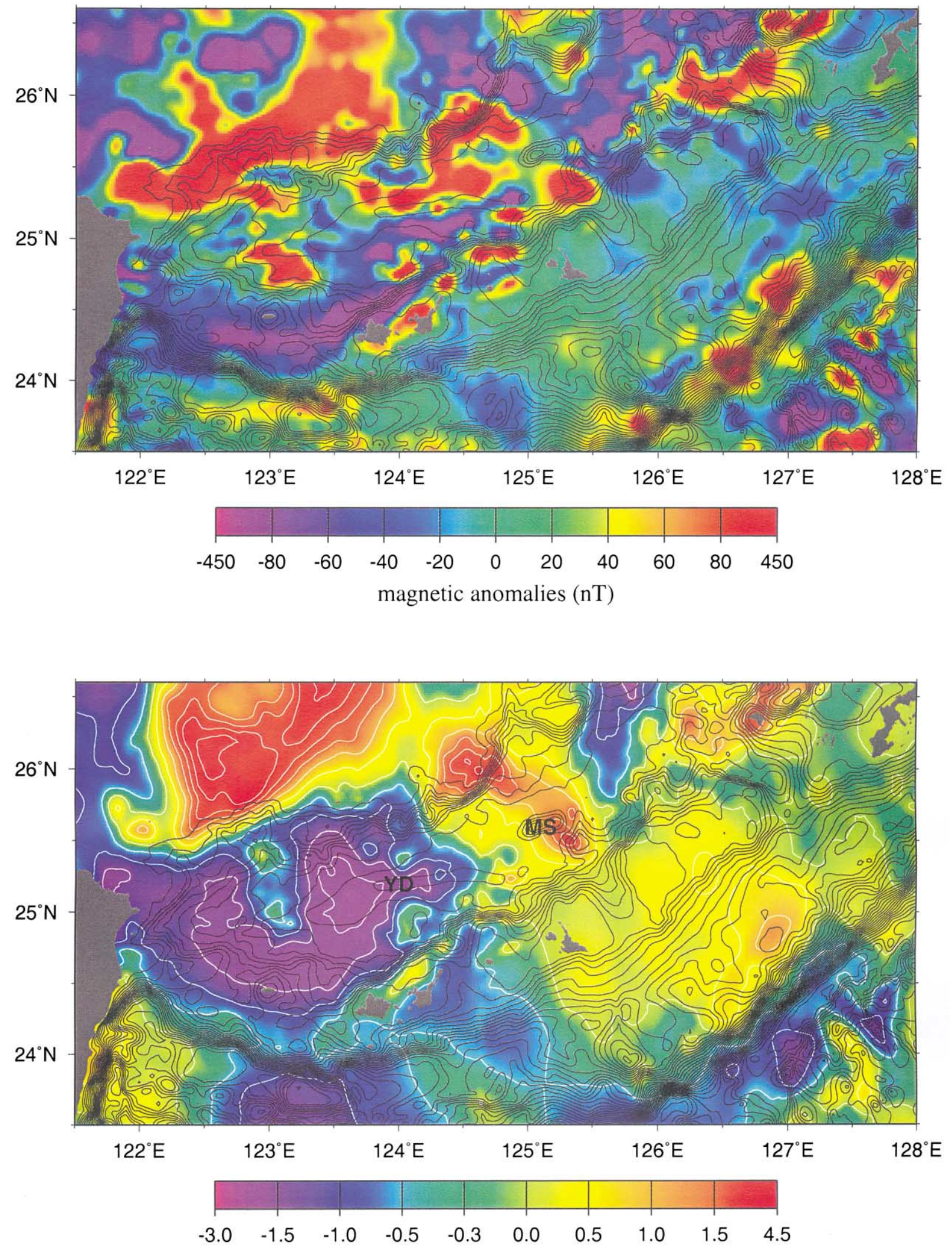


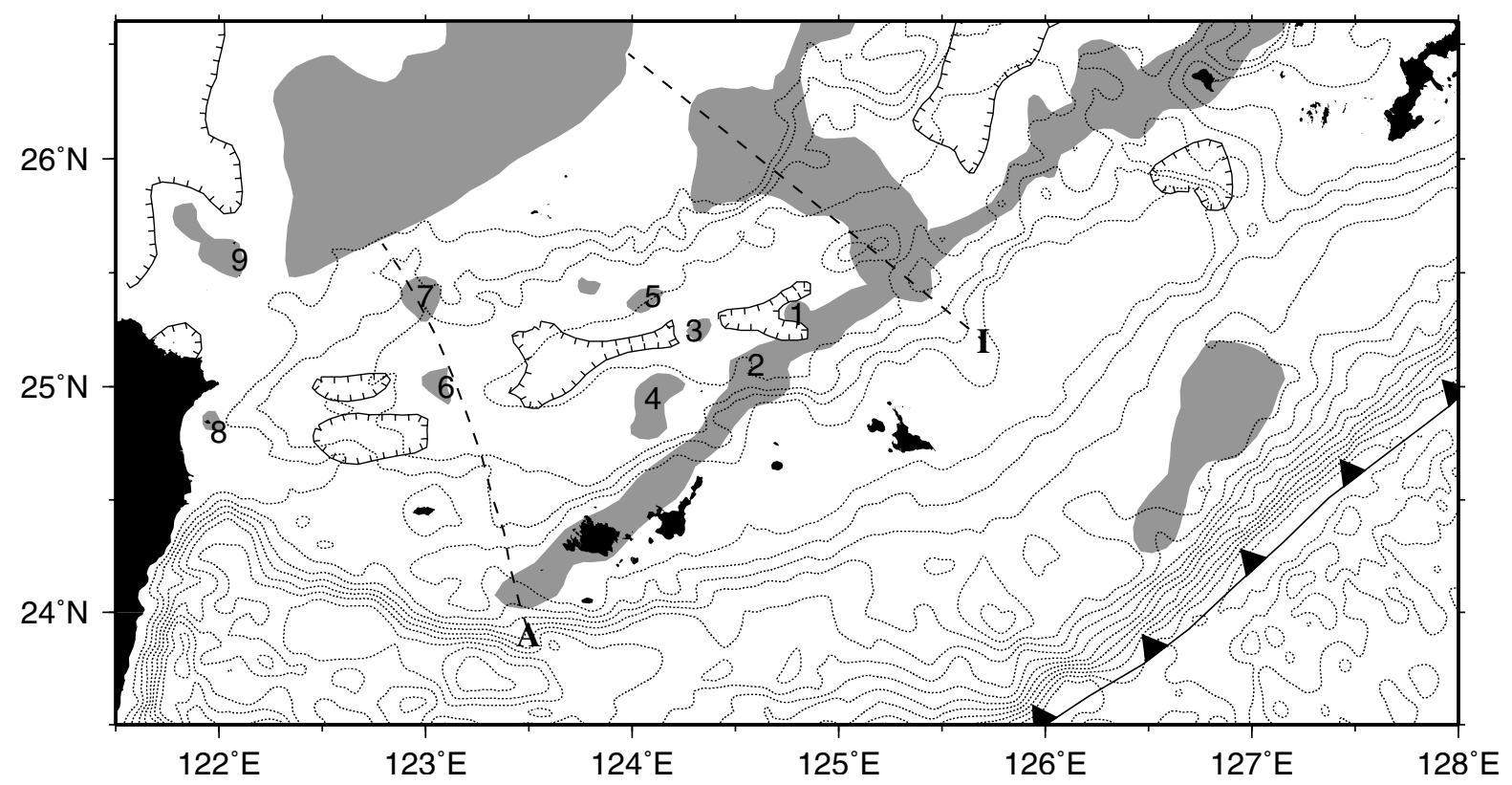

Fig. 7. Interpreted volcanic features from relative high magnetization areas in Fig. 6b. References in parenthesis indicate that corresponding volcanic features can be identified by volcanic rocks, seismic profiles and/or high-resolution bathymetry. 1: Irabu sea-knoll (Furukawa et al., 1991). 2: Tarama sea-knoll (Furukawa et al., 1991). 3: Yaeyama Central sea-knoll (Sibuet et al., 1987; Furukawa et al., 1991). 4: Ishigaki seaknoll (Furukawa et al., 1991). 5: Possible volcanic intrusion or sea-knoll covered by thick sediments. It is symmetric to the Ishigaki sea-knoll with respect to the central E-W trending Yaeyama Depression. 6: Seamounts revealed by high-resolution bathymetry (Sibuet et al., 1998). 7: Volcanic intrusion revealed by seismic reflection profiles (Ho-Shing Yu, personal communication). 8: Holocene volcanic Kueishantao islet (Chen et al., 1998). 9: Volcanic Pleistocene Menhuahsu islet area (Wang et al., 1999). Dashed line I indicate the location of the MiyakoYandang high-magnetization zone. Dashed line A indicates the different rifting regimes on both sides of the southern Okinawa Trough.

associated with the Ryukyu subduction zone are NESW trending.

The magnetization magnitudes are generally larger in the southern portion of the study area (Fig. 4b). We can roughly divide the distribution of the magnetization magnitudes into three domains separated by dashed lines indicated by I and II in Fig. 5. As also inferred from gravity anomalies (Fig. 2), strike-slip faults may exist along those lines (Fig. 3) (Liu, 1992). High magnetizations are generally located in the domain between I and II (Figs. $4 \mathrm{~b}$ and 5). The reasons for the high-magnetization area can be a highly magnetized and/or a shallow basement. The latter case was suggested by Liu (1992). The region north of II displays, in contrast, relatively low magnetization.
The Hupijiao and Haijiao belts in this region do not have a clear trend (Figs. 4b and 5).

\subsection{Initial opening of the Okinawa Trough}

The change in orientation of the belts from the East China Sea to the Okinawa Trough is in favor of a major tectonic event along the eastern side of the Taiwan-Sinzi belt. Le Pichon and Mazzotti (1997) proposed that this event is a major dextral strikeslip faulting (Fig. 2) between $\sim 30$ and $15 \mathrm{Ma}$ and the initial opening of the middle and northern Okinawa Trough started afterwards. Because the volcanic belts to the east of the Taiwan-Sinzi belt are rather parallel to the Ryukyu trench (Fig. 5), the

Fig. 6. (a) (Upper) Detailed magnetic anomalies from Hsu et al. (1998) and Sibuet et al. (1995). Bathymetry of $200 \mathrm{~m}$ contour interval is superposed. (b) (Lower) The equivalent magnetizations of the same area as Fig. 4b. YD: Yaeyama Depression. MS: Miyako seamount. 
rifting of the middle and northern Okinawa Trough may be controlled by the northwestward subduction of the Philippine Sea Plate beneath the Ryukyu island arc. Le Pichon and Mazzotti (1997) suggested that the southern end of the major fault was near the Kerama Gap beneath which there is a crustal discontinuity (Kodaira et al., 1996). A remarkable magnetization contrast near the Kerama Gap confirms the presence of the crustal discontinuity (Fig. 4b). This structure could correspond to a NW-SE-trending fault zone (cf. Figs. 2 and 4b) (Liu, 1992). However, the quasi-linear Taiwan-Sinzi belt seems to terminate at a high-magnetization structure trending NW-SE (Figs. 4b and 5). It is noted that the highmagnetization structure is located in the southwest of the Kerama Gap. Because the Miyako seamount is located at this structure, we call, for convenience, this NW-SE trending high magnetization the "Miyako-Yandang high-magnetization zone" (Fig. 5).

Conventionally the southern Okinawa Trough is considered to be the bathymetric depression between the Kerama Gap and the Ilan Plain in northeastern Taiwan. We define the southern Okinawa Trough as the region between the Miyako-Yandang highmagnetization zone and the Ilan plain. This new definition is significant because the sedimentation and the rifting evolution in this portion are strikingly different from the rest of the Okinawa Trough. The southern Okinawa Trough does not contain the seismic stratigraphy corresponding to the Pliocene Shimajiri Group of the Ryukyu arc; thus, the rifting of the southern Okinawa Trough could have initiated in early Pleistocene age (Park et al., 1998).

The southern end of the Taiwan-Sinzi belt was long considered to be in the northeastern Taiwan (e.g. Wang and Hilde, 1973; Sun, 1981; Sibuet et al., 1998). In other words, it was taken for granted that the Taiwan-Sinzi belt bounds the northern margin of the Okinawa Trough. As shown above, the Miyako-Yandang high-magnetization zone marks the southern end of the Taiwan-Sinzi belt. The high magnetization or the high-gravity anomalies bounding the northern margin of the southern Okinawa Trough could be de facto linked to the southern portion of the Yushan belt (Figs. 4b and 5). However, with respect to the regular trend of the belts in the East China Sea, this portion seems to be bent clockwise (Fig. 5). It suggests that prior to the opening of the southern Okinawa Trough, the northern margin of the southern Okinawa Trough could have been under compressive deformation at $\sim 7-6 \mathrm{Ma}$ (Hsu et al., 1997). Structural folds are recognized by seismic reflection profiles (Letouzey and Kimura, 1986; Sibuet et al., 1998). Accordingly, the three NW-SE trending major strike-slip faults or crustal discontinuities in the southwestern end of the Okinawa Trough (Hsu et al., 1996) or the clockwise rotated south Ryukyu arc between $\sim 10$ and $6 \mathrm{Ma}$ (Miki, 1995) could be linked to that compression. The opening mechanism of the southern Okinawa Trough is thus quite different from the middle and northern Okinawa Trough, which generally exhibits a typical backarc basin.

\subsection{Detailed volcanic features in the southern Okinawa Trough}

On the basis of the magnetization characteristics, the southern Okinawa Trough is composed of two different patterns (Figs. 6b and 7). The region west of line A, called Taiwan-Ryukyu Faulted Zone, comprises several NW-SE trending strike-slip faults (Fig. 6b) (Hsu et al., 1996). Submarine canyons and volcanism have developed along these fractures at the northern margin of the trough (Fig. 6b). Relatively central magnetization high can be observed along the trough axis (Fig. 6b). In contrast, the region between line A and the Miyako-Yandang highmagnetization zone contains no clear NW-SE trending feature. The magnetization distribution suggests a quasi-symmetric rifting pattern with respect to the central, bathymetric depression or graben (e.g. structures 4 and 5 in Fig. 7). However, the rifting rate along the Yaeyama Depression does not seem uniform because high-magnetization areas, such as the Yaeyama central sea-knoll (structure 3 in Fig. 7) or the Irabu sea-knoll (structure 1 in Fig. 7), are not evenly distributed. The backarc rifting associated with the occurrence of volcanic sea-knolls is active because the ages of the Yaeyama and Irabu seaknolls are identified as 0.62 and $0.51 \mathrm{Ma}$ only (Ishikawa et al., 1991). It is noted that the Irabu seaknoll is also located on the present-day Ryukyu arc belt. 


\subsection{Volcanism and shape of the Wadati-Benioff zone}

East of line A, the present-day Ryukyu arc volcanism is well correlated with a relatively highmagnetization area; whereas, west of line A, the Ryukyu arc exhibits very low magnetization (Figs. 5 and 7). The low magnetization reflects the non-volcanic nature of the south Ryukyu arc, at least after Eocene (Kizaki, 1986).

In addition to separating the southern Okinawa Trough from the rest of the Okinawa Trough, the Miyako-Yandang high-magnetization zone surprisingly marks a change in depth of the Wadati-Benioff zone below the Ryukyu subduction zone (Fig. 1). Northeast of the Miyako-Yandang high-magnetization zone, the 100-km isocontour of the Wadati-Benioff zone follows the northern flank of the middle and northern Ryukyu arc, which corresponds to the location of the present-day Ryukyu arc volcanism. In contrast, southwest of the Miyako-Yandang highmagnetization zone, the $100 \mathrm{~km}$ isocontour follows the southern portion of the southern Okinawa Trough. The isocontour seems to hinge on the MiyakoYandang high-magnetization zone and rotate clockwise. This phenomenon is even clearer for the 200-km isocontour of the Wadati-Benioff zone (Fig. 1): the $200-\mathrm{km}$ isocontour follows the central trough in the middle and northern Okinawa Trough; yet, it is below the northern margin of the southern Okinawa Trough. In addition, the Northern Taiwan Volcanic Zone (Wang et al., 1999) is only distributed to the southwest of the Miyako-Yandang high-magnetization zone (Fig. 1).

\section{Conclusion}

On the basis of the distribution of the equivalent magnetizations, we have attempted to outline the general tectonic configuration of the eastern margin of the Eurasian plate. The continental rifting in the East China Sea shelf basin has taken place in the southeastward direction, producing several rifted ridges (or belts) and basins in between. The belts display a general $\mathrm{N} 075^{\circ}$ trend and rotate $20^{\circ}$ clockwise from the East China Sea to the Ryukyu subduction zone. This change in belt orientation indicates that the east side of the Taiwan-Sinzi belt was imprinted by an important tectonic event. The belts in the Ryukyu subduction system are generally parallel to the Ryukyu trench and thus the rifting of the Okinawa Trough could be controlled by the subduction of the Philippine Sea plate beneath the Ryukyu island arc.

The southern end of the Taiwan-Sinzi belt terminates against the NW-SE trending Miyako-Yandang high-magnetization zone. South of the high-magnetization zone, the trough is defined as the southern Okinawa Trough. The southern Okinawa Trough, rifted since early Pleistocene, consists of two different rifting patterns. East of $123.5^{\circ} \mathrm{E}$, the relative highmagnetization areas symmetrically on both sides of the Yaeyama Depression reveal quasi-symmetric backarc rifting. West of $123.5^{\circ} \mathrm{E}$, relative high magnetization along the central trough is present, but no clear symmetric rifting pattern is observed. Volcanism, exhibited by high magnetization, has occurred along existing NW-SE trending fractures, especially at the northern margin of the southern Okinawa Trough.

\section{Acknowledgements}

We would like to thank Dr L.-Y. Chiao for his help in using the LSQR algorithm. Special thanks are due to National Science Council (NSC), ROC and Institut Français à Taiwan (IFT), France for their continuous supports in the Sino-French cooperation in Earth Sciences and Oceanography. Computer facilities were mainly provided by the College of Earth Sciences of National Central University, Taiwan, ROC. Comments from Drs C.-S. Lee and K. Okino and one anonymous reviewer provided significant improvement. Constructive remarks from Editor J.-P. Burg are appreciated.

\section{References}

Chen, Y.-G., Wu, W.-S., Liu, T.-K., Chen, C.-H., 1998. A Holocene volcanic island: Kueishantao. Annual Meeting of Geological Society of China, Program and Abstracts, 104.

Furukawa, M., Tokuyama, H., Abe, S., Nishizawa, A., Kinoshita, H., 1991. Report on DELP 1988 Cruise in the Okinawa Trough. Part 2. Seismic reflection studies in the southwestern part of the Okinawa Trough. Bull. Earthquake Res. Inst., Univ. Tokyo 66, 17-36. 
Hsu, S.-K., Liu, C.-S., Shyu, C.-T., Liu, S.-Y., Sibuet, J.-C., Lallemand, S., Wang, C., Reed, D., 1998. New gravity and magnetic anomaly maps in the Taiwan-Luzon region and their preliminary interpretation. Terr. Atmos. Oceanic Sci. 9, 509-532.

Hsu, S.-K., Sibuet, J.-C., Monti, S., Shyu, C.-T., Liu, C.-S., 1996. Transition between the Okinawa trough backarc extension and the Taiwan collision: new insights on the southernmost Ryukyu subduction zone. Mar. Geophys. Res. 18, 163-187.

Hsu, S.-K., Sibuet, J.-C., Shyu, C.-T., Liu, C.-S., Deffontaines, B., Lallemand, S., 1997. A note on the tectonic features and volcanism of the southern Okinawa Trough. International Conference and Sino-American Symposium on Tectonics of East Asia, Program and Abstracts, 88.

Huang, S.-T., Ting, H.-H., Chen, R.-C., Chi, W.-R., Hu, C.-C., Shen, H.-C., 1992. Basinal framework and tectonic evolution of offshore northern Taiwan. Petrol. Geol. Taiwan 27, 47-72.

Ishikawa, M., Sato, H., Furukawa, M., Kimura, M., Kato, Y., Tsugaru, R., Shimamura, K., 1991. Report on DELP 1988 Cruise in the Okinawa Trough. Part 6: Petrology of volcanic rocks. Bull. Earthquake Res. Inst., Univ. Tokyo 66, 151-177.

Kizaki, K., 1986. Geology and tectonics of the Ryukyu islands. Tectonophysics 125, 193-207.

Kodaira, S., Iwasaki, T., Urabe, T., Kanazawa, T., Egloff, F., Makris, J., Shimamura, H., 1996. Crustal structure across the Middle Ryukyu trench obtained from ocean bottom seismographic data. Tectonophysics 263, 39-60.

Le Pichon, X., Mazzotti, S., 1997. A new model for the early opening of the Okinawa basin. Proceedings of Chinese Taipei ODP Consortium 1997 Annual Meeting and Long-Range Plan for Chinese Taipei Ocean Drilling Program Workshop, Taipei, Taiwan, 6 November 1997, 34 pp.

Lee, C.-S., Shor Jr, G.G., Bibee, L.D., Lu, R.S., Hilde, T.W.C., 1980. Okinawa Trough: origin of a backarc basin. Mar. Geol. 35, 219-241.

Letouzey, J., Kimura, M., 1986. The Okinawa Trough: genesis of a backarc basin developing along a continental margin. Tectonophysics 125, 209-230.

Liu, C.-S., Liu, S.-Y., Lallemand, S.E., Lundberg, N., Reed, D.L., 1998. Digital elevation model offshore Taiwan and its tectonic implication. Terr. Atmos. Oceanic Sci. 9, 705-738.

Liu, G., 1992. Geologic-Geophysic Features of China Seas and Adjacent Regions. Science Press, Beijing (424 pp.) (in Chinese)..

Magnetic Anomaly Map of East Asia, 1994. In Geological Survey of Japan and Committee for Co-ordination of Joint Prospecting for Mineral Resources in Asian offshore areas (CCOP).

Menke, W., 1984. Geophysical Data Analysis: Discrete Inverse Theory. Academic Press, London (260 pp.).

Miki, M., 1995. Two-phase opening model for the Okinawa trough inferred from paleomagnetic study of the Ryukyu arc. J. Geophys. Res. 100, 8169-8184.

Oshida, A., Tamaki, K., Kimura, M., 1992. Origin of the magnetic anomalies in the southern Okinawa trough. J. Geomag. Geoelectr. 44, 345-359.

Paige, C.C., Saunders, M.A., 1982. LSQR: an algorithm for sparse equations and sparse least squares. ACM Math. Softw. 8, 4371.

Park, J.-O., Tokuyama, H., Shiohara, M., Suyehiro, K., Taira, A., 1998. Seismic record of tectonic evolution and backarc rifting in the southern Ryukyu island arc system. Tectonophysics 294, 21-37.

Sibuet, J.-C., Hsu, S.-K., 1997. Geodynamics of the Taiwan arc-arc collision. Tectonophysics 274, 221-251.

Sibuet, J.-C., Deffontaines, B., Hsu, S.-K., Thareau, N., Le Formal, J.-P., Liu, C.-S., ACT party, 1998. Okinawa trough backarc basin: early tectonic and magmatic evolution. J. Geophys. Res. 103, 30245-30267.

Sibuet, J.-C., Hsu, S.-K., Shyu, C.-T., Liu, C.-S., 1995. Structural and kinematic evolutions of the Okinawa trough backarc basin. In: Taylor, B. (Ed.), Backarc Basins: Tectonics and Magmatism. Plenum Press, New York, pp. 343-379.

Sibuet, J.-C., Letouzey, J., Barrier, F., Charvet, J., Foucher, J.-P., Hilde, T.W.C., Kimura, M., Chiao, L.-Y., Marsset, B., Muller, C., Stephane, J.-F., 1987. Back arc extension in the Okinawa trough. J. Geophys. Res. 92, 14041-14063.

Smith, W.H.F., Sandwell, D.T., 1997. Global sea floor topography from satellite altimetry and ship depth soundings. Science 277, 1956-1962.

Sun, S.-C., 1981. The Tertiary basin offshore Taiwan. Proceedings of ASCOPE Conference and Exhibition, Manila, Philippines, pp. 126-135.

Wang, C., Hilde, T.W.C., 1973. Geomagnetic interpretation of the geologic structure in the northeast offshore region of Taiwan. Acta Oceanogr. Taiwan 3, 141-156.

Wang, K.-L., Chung, S.-L., Chen, C.-H., Shinjo, R., Yang, T.F., Chen, C.-H., 1999. Post-collisional magmatism around northern Taiwan and its relation with opening of the Okinawa Trough. Tectonophysics 308, 363-376. 